УДК 621.431 .73

ББК 39.3

\title{
VALVE CAM DESIGN USING NUMERICAL STEP-BY-STEP METHOD
}

\author{
Vasilyev Aleksandr Viktorovich \\ Doctor of Technical Sciences, Professor, Head of the Department of Car-and-Tractor Engines, \\ Volgograd State Technical University \\ atd@vstu.ru, vasilyev@vstu.ru \\ Prosp. Lenin, 28, 400005 Volgograd, Russian Federation
}

\section{Bakhracheva Yuliya Sagidullovna}

Candidate of Technical Sciences, Associate Professor, Department of Physics and Chemistry, Moscow State University of Communication Means, Volgograd Branch bakhracheva@yandex.ru Bukhantseva St., 48, 400120 Volgograd, Russian Federation

\section{Kabore Ousman}

Candidate of Technical Sciences, Professor,

Polytechnic University of Bobo-Dioulasso

atd@vstu.ru

Bobo-Dioulasso, Burkina Faso

\section{Zelenskiy Yuriy Olegovich}

Degree Seeking Candidate, Department of Car-and-Tractor Engines, Volgograd State Technical University

atd@vstu.ru, vasilyev@vstu.ru

Prosp. Lenin, 28, 400005 Volgograd, Russian Federation

\begin{abstract}
This article studies the numerical step-by-step method of cam profile design. The results of the study are used for designing the internal combustion engine valve gear. This method allows to profile the peak efficiency of cams in view of many restrictions, connected with valve gear serviceability and reliability.

Key words: cam, profile, step-by-step method, numerical method, design, valve gear, tappet, motion law.
\end{abstract}

\section{INTRODUCTION}

Now the problem of the cam design providing required characteristics of gear parts movement in a combination with its reliability is actual. For the solution of the given problem authors develop a numerical method of cams profiling. In the given work this method is considered with reference to internal combustion engine valve gear, however it also can be used 
for designing other cam mechanisms with the purpose to increase their reliability.

There are two basic approaches to cam design. According to the first, the cam profile geometry is set, and then speed and acceleration tappet functions depending on cam rotation angle are determined. In the second case the law of tappet movement is initial and on its basis a configuration of the cam and data, necessary for its manufacturing, are determined.

It is necessary to note, that each of traditional methods of the cam profiling have their scopes. For example, cams of the first group, for which the discontinuous tappet acceleration is typical, are inapplicable for high-speed engines owing to unsatisfactory valve gear dynamics. Besides as a rule, it is difficult to detemine valve gear optimum parameters values, satisfying numerous requirements, connected with gas exchange in the engine, kinematics, dynamics and reliability of the mechanism, and also technological restrictions. The problem is complicated also as to each method a set of the parameters determining the profile corresponds. At last, preset ways of the tappet movement description or the profile configuration even in case of an optimum parameters choice do not provide design of maximum efficiency cams at realization of the mentioned above conditions.

\section{MATHEMATICAL MODEL AND RESULTS}

Referred above disadvantages can be eliminated using the generalized numerical method of valve gear cam design, which allows on the basis of the uniform approach to profile the cams satisfying various conditions. Its basis is a principle of step-by-step formation of the tappet movement law taking into account set restriction [2], which permit to refuse of beforehand accepted cam profile description. Thus, instead of the analytical law of tappet movement the numerical representation is used, and the algorithm of positive and negative acceleration forming provides the peak cam efficiency, depending on the tappet displacement diagram completeness and connected to its valve timing.
The basic restrictions, connected with requirements on serviceability and reliability of valve gear system:

$$
\begin{gathered}
\sigma \leq[\sigma] ;|\chi| \leq[\chi] ; r \notin(-\Delta / 2,0) ; k \geq[k] \\
\left.h_{\min } \geq h_{\min }\right]
\end{gathered}
$$

where: $\sigma-$ a contact stress in cam-tappet pair; $\chi-\mathrm{a}$ pressure angle; $r$ is radius of cam profile curvature; $\Delta$-diameter of a roller or a abrasive disc; $k$-coverage factor of the valve springs effort; $h_{\min }-$ minimal oil film thickness in the cam-tappet pair, considered under formulas of elastohydrodynamics.

In brackets the admitted values of corresponding parameters are resulted. As the parameters, describing hydrodynamical conditions of the oil film formation in cam-tappet pair, alongside with thickness $h_{\text {min }}$ also hydrodynamically effective speed $V_{2}$ or dimensionless parameter $\gamma$ can be used. Analytical dependences for the calculation of listed parameters for various valve gear kinematic schemes are presented, for example, in work [1].

At synthesis of tappet movement characteristics along with (1) the restrictions on the higher order of derivative from the tappet displacement $s$ on the cam angle of turn $\varphi$ is also taken into consideration:

$$
s_{\text {min }}^{(m)} \leq s^{(m)} \leq s_{\text {max }}^{(m)}(m=2, \ldots, n),
$$

where: $m$ is the order of a derivative; $n$ is its maximum value; $s_{\min }^{(m)}$ and $s_{\max }^{(m)}$ is the minimal and maximal allowable values of derivative $s^{(m)}$ accordingly.

Limitations (2) can be accepted as for all work profile part, and separately for certain areas $\Omega_{i}$ of cam turn angle $\varphi$ change (for example, parts of the tappet positive and negative acceleration).

At the end of the negative part of tappet acceleration (the point $\mathrm{C}$ on Fig. 1) the specified boundary conditions are provided: values of the tappet maximal displacement and its derivatives on the cam turn angle on $(n-1)$ order inclusive (the value of speed $\dot{s}$ and, hence, its analogue $\mathrm{s}^{\prime}$ in the given point is necessary to equal to zero). Equality of corresponding boundary conditions in this point during formation of the tappet raising and lowering laws provides continuity of 


\section{ТЕХНИКО-ТЕХНОЛОГИЧЕСКИЕ ИННОВАЦИИ}

characteristics at the top of the cam. At the beginning of the tappet positive acceleration part (point A on Fig. 1) also are set the boundary conditions allowing, in particular, to integrate the basic part of the cam profile with runout. So, on Fig. 2.c and 2.d (the side of lowering) a continuity of functions $s(\varphi), s^{\prime}(\varphi), s^{\prime \prime}(\varphi), s^{\prime \prime \prime}(\varphi)$ is provided at conjunction of runout and the basic part of profile.

The law of tappet movement is formed with enough small step $\Delta \varphi$ on the cam turn angle. Step-by-step synthesis of positive $A B$ and negative BC (Fig. 1) tappet acceleration parts begins accordingly from points $\mathrm{A}$ and $\mathrm{C}$, in which boundary conditions are set. It is known, that area $F_{\mathrm{s}}$ under the curve of tappet displacement grows with increase of a positive level and reduction of a negative level of the tappet acceleration. So, on each step the maximal value of the second derivative module s", admitted by available limitations (1) and (2), gets out.

Values $s^{\prime}$ and $s$ are defined by numerical integration, but derivative $\mathrm{s}^{\prime \prime \prime}$ and higher orders numerical differentiation of formed function $s^{\prime \prime}(\varphi)$, set in the table. During simultaneous synthesis of parts $\mathrm{AB}$ and $\mathrm{BC}$ the current values $\mathrm{s}^{\prime}$ in points $\mathrm{B}_{+}$and $\mathrm{B}_{-}$differ from each other no more than on some value, determined by set accuracy (Fig. 1.a1.c). When the values of displacement $s$ in these points become identical (Fig. 1.c), additional alignment of values $s$ and its derivatives according to (2) in a joint of positive and negative acceleration is made. Thus, jump of the second derivative $\mathrm{s}^{\prime \prime}$ can be limited by the set value $\Delta s_{B}^{\prime \prime}$
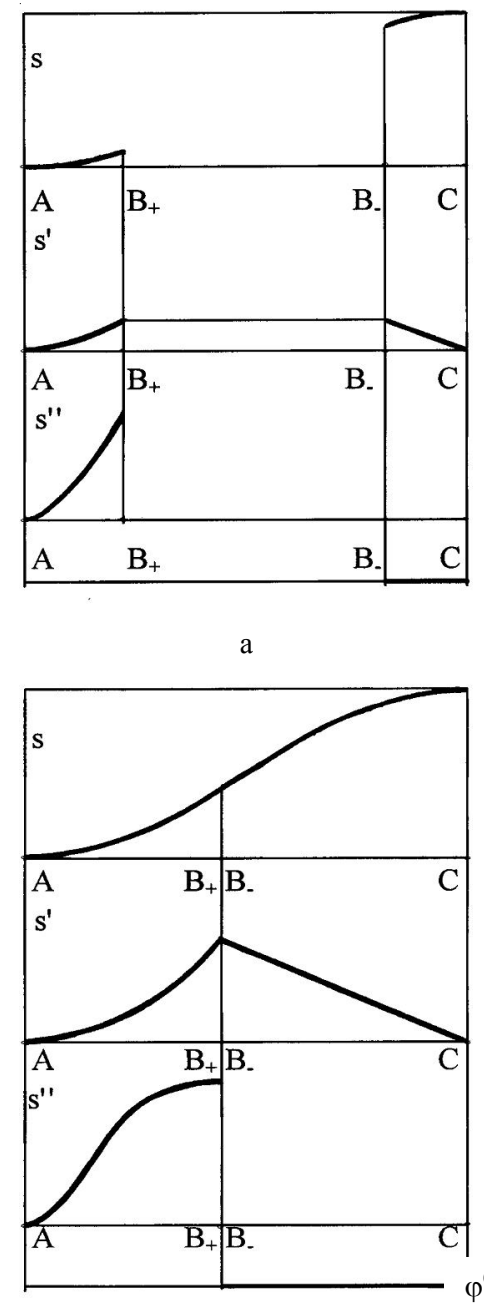

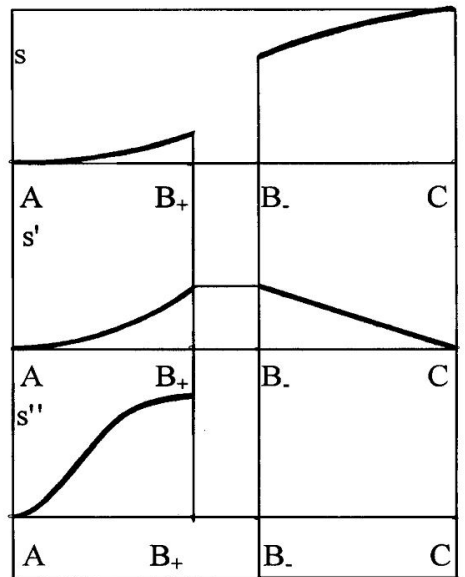

b

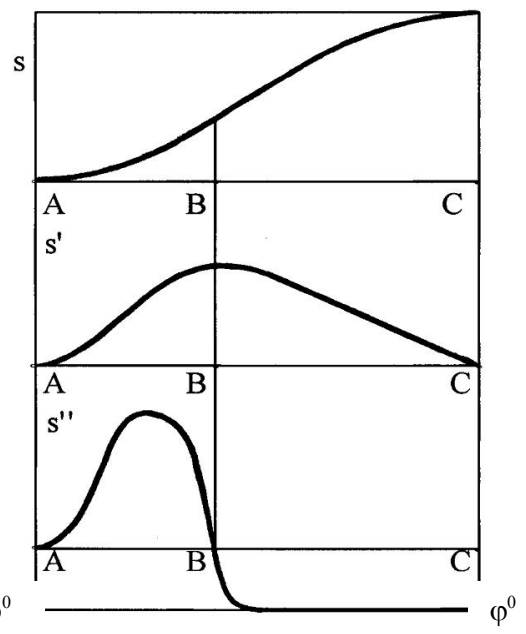

d

Fig. 1. Successive stages (from 1.a to 1.d) of tappet raising law formation using step-by-step numerical method 


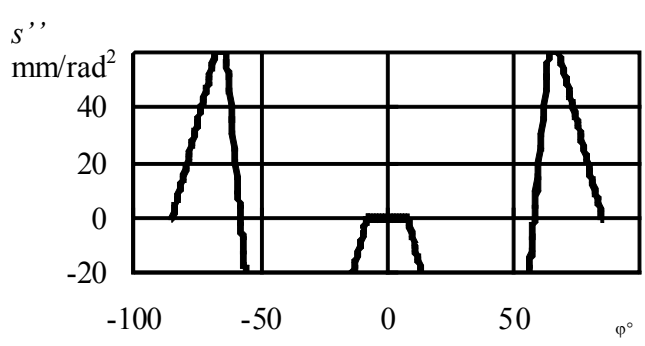

a

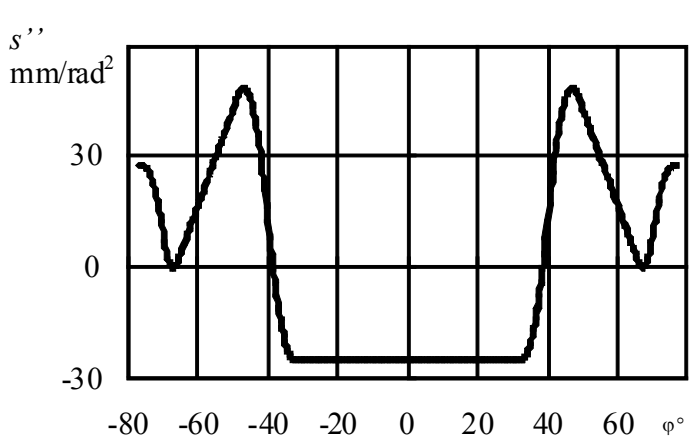

c

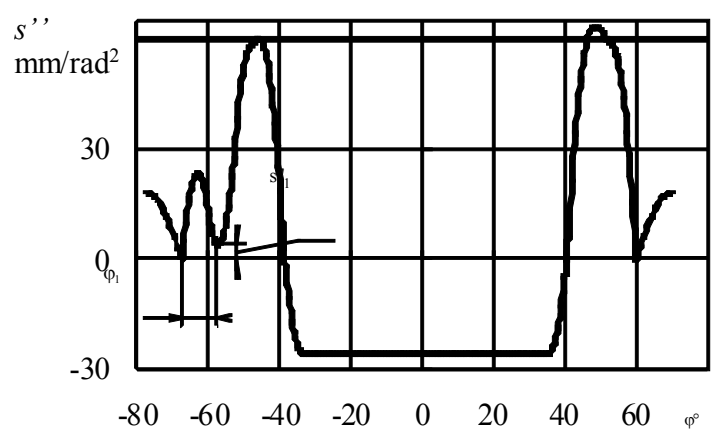

$\mathrm{e}$

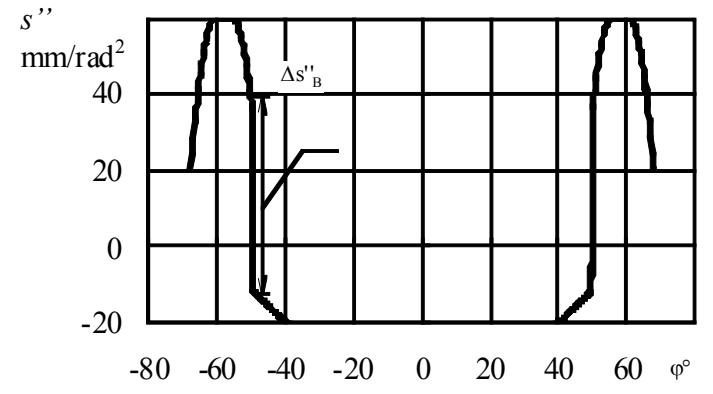

b

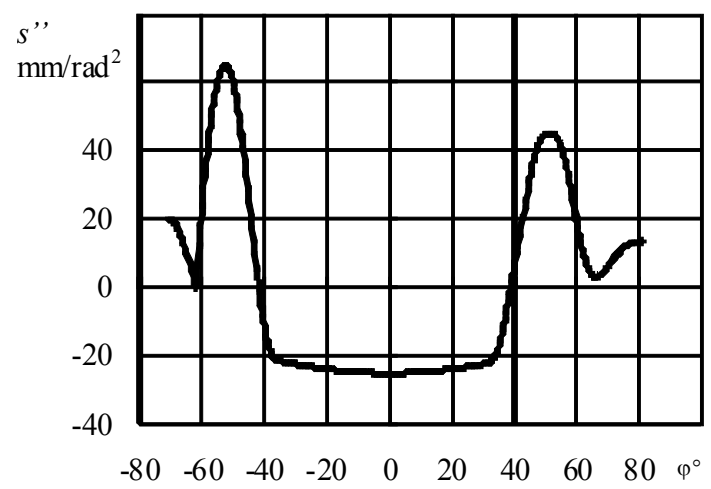

d

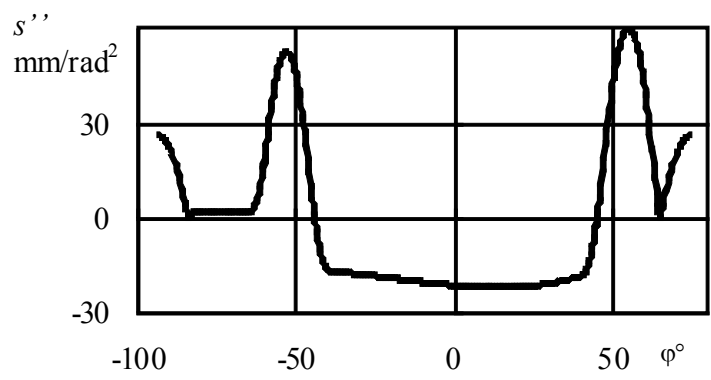

$\mathrm{f}$

Fig. 2. Laws of the tappet acceleration analogue change on a turn angle of the cam, profiled by numerical method

(Fig. 2.b). In that specific case $\Delta s_{B}=0$, and the curve of acceleration is continuous (Fig. 1.d).

During step-by-step synthesis of the tappet movement law it is provided the opportunity to vary over a wide range smoothness of the acceleration curve and extents of its parts of positive and negative values by change of restrictions (2). It allows to form laws of tappet movement, combining high dynamic qualities and efficiency in compliance with specific speed and conditions of the engine operation. For example, for $n=2$ (see restriction (2)) in area $\Omega_{1}$, corresponding to all part of tappet raising or lowering, the analogue of its positive acceleration is limited by the set value $s_{\max }^{\prime \prime}$, and negative $-s_{\min }^{\prime \prime}$. However, the acceleration is discontinuous in a point of a joint of positive and negative parts, that, as known, can degrade the valve gear dynamics.

In a case $n=3$ this discontinuous break is eliminated, and character of the acceleration change will be determined by values $s_{\min }^{\prime \prime}$ and $s_{\max }^{\prime \prime \prime}$ Those values, according to (2), can be set 
separately of positive and negative acceleration parts by a corresponding choice of areas $\Omega_{i}$. Thus, a trapezoidal law of the acceleration change is formed, if all of limitations (1) are not active. The example of the acceleration law as asymmetrical trapeze is presented on Fig. 2.a.

Using (2) at $n>3$ will lead to the subsequent increase of the tappet movement law smoothness with the purpose of the loading valve gear decrease. So, at $n=4$ the continuity of the third derivative $\mathrm{s}^{\prime \prime \prime}(\mathrm{j})$ (Fig. 2.c, 2.f) is provided. At the corresponding extremely admitted values of derivatives on certain parts $\mathrm{W}_{i}$ according to (2) the asymmetrical part of positive acceleration (Fig. 2.c) can be generated. It allows to receive smoother change of acceleration in the beginning of the positive part AB (Fig. 2.c), that promotes to reduce the revolting cam influence on the valve gear elements in initial phase of tappet raising and during valve lowering on the seat.

Because of requirements distinction to the cam sides, corresponding to tappet rising and lowering (for example, for runout), and also because of valve gear kinematics speciality, the asymmetrical tappet movement concerning top of the cam can be received. Essential asymmetry takes place at appreciably smaller acceleration values and at smoother change of the acceleration during tappet lowering in comparison with rising (Fig. 2.d), that also improves conditions of the valve planting on the seat.

For the increase of the area $F_{\mathrm{s}}$ under the tappet displacement curve at step-by-step formation of the tappet movement law the opportunity of tappet top standing is stipulated by the corresponding set of boundary conditions in p. C (Fig. 1). Thus, the acceleration curve can be as discontinuous (that even more increases $F_{s}$ ), and continuous (Fig. 2.a). Besides, during all working cam profile, including top standing, it is continuous not only displacement, but also analogues of tappet speed and acceleration, and derivatives of higher order.

On the basis of the step-by-step numerical method the technique of the tappet movement law formation with dynamic adjustment for the certain speed regime is offered. It allows to reduce oscillations intensity in valve gear (in the executed calculations - up to $24 \%$ ) to lower dynamic loadings and to remove breaks in the gear kinematic circuit. It is reached by introduction of additional restriction of a kind (2) on the tappet positive acceleration part. So, if to accept, that some area $\Omega_{i}$ will consist of one point with coordinate $\varphi_{1}$, in which $s_{\min }^{\prime \prime}=s_{\max }^{\prime \prime}=s_{1}^{\prime \prime}$, maximization of the acceleration on its positive part enables formations of two maximums: before and after $\varphi_{1}$ (Fig. 2.e).

Effective dynamic adjustment with the purpose of suppression of oscillations, appearing in valve gear, is possible only at a correct choice of parameters $\varphi_{1}$ and $s_{1}^{\prime \prime}$. It is carried out by optimization in the set ranges in a combination with mathematical simulation of valve gear dynamics. Thus the given approach has a number of advantages in comparison with the known method polydyne [1], where the tappet acceleration curve on all extent of its rising or lowering is described by uniform analytical functional dependence - a polynomial. Really, the received law is not described by preset ways, but formed proceeding from the set restrictions (1) and (2), which can be active on parts of significant extent, that promotes growth of the efficiency, determined by $F$, and by satisfaction of requirements on serviceability and reliability parameters.

Using given method it is also possible to introduce some kinematic restrictions on the tappet movement law, connected, for example, with the inflow gas dynamics, with inadmissibility of valvepiston meeting or with the decrease of hydraulic impact dynamic influence on the valve gear using regulation hydraulic systems. In particular, in Fig. 2.f the law s" $(\varphi)$ with the limited tappet displacement in the initial phase of its rising is resulted.

\section{CONCLUSIONS}

It is important to note, that presence of restrictions (1) and (2) allows to take into account valve gear type and parameters at formation of the tappet movement law. Because the acceleration curve is not described by any analytical dependences, but formed numerically under influence of those or other requirements, there is an alignment of characteristics on a angle of the cam turn, that promotes, in particular, to more uniform cam-tappet wear process and increase of the system reliability. Besides it is grows its efficiency as the accepted restrictions can be active on significant extent parts of the characteristics, instead of in separate points as it takes place at use of traditional methods. 


\section{ТЕХНИКО-ТЕХНОЛОГИЧЕСКИЕ ИННОВАЦИИ}

The character of tappet acceleration change on a cam turn angle at active restriction, for example, on a contact pressure, depends on profile curvature radius, valve gear springs effort, the concrete sizes and design features of valve gear. Therefore the existing traditional methods, based on preset ways of the analytical description of the tappet movement law, allow only to come nearer to some extent on efficiency to the movement laws received by a numerical method. It is necessary to note also, that alignment of values of a contact pressure in a cam - tappet pair on a cam turn angle using step-by-step numerical method allows to receive full-strength profile in the field of the greatest $\sigma$ values.
Alongside with formation of the tappet movement law definition of the necessary data for manufacturing and the control of the corresponding cam profile using various kinematic schemes is stipulated. Efficiency of a considered method has been confirmed at profiling cams for lines of tractor and automobile engines.

\section{REFERENCES}

1. Korchemniy L.V. Automobile Engine Distribution Mechanism: Kinematics and Dynamics. 2 ed. Moscow, Mechanical Engineering Publ., 1981. 191 p.

2. Vasilyev A.V., Grigoryev E.A. Numerical Method of the Cams Profiling. Motor Industry, 1999, no. 11, pp. 22-25.

\section{ПРОЕКТИРОВАНИЕ КУЛАЧКА КЛАПАННОГО МЕХАНИЗМА НА ОСНОВЕ ЧИСЛЕННОГО ПОШАГОВОГО МЕТОДА}

\section{Васильев Александр Викторович}

Доктор технических наук, профессор, заведующий кафедрой автотракторных двигателей Волгоградского государственного технического университета atd@vstu.ru, vasilyev@vstu.ru просп. Ленина, 28, 400005 г. Волгоград, Российская Федерация

\section{Бахрачева Юлия Сагидулловна}

Кандидат технических наук, доцент кафедры физики и химии Московского государственного университета путей сообщения (МИИТ), Волгоградский филиал bakhracheva@yandex.ru ул. им. милиционера Буханцева, 48, 400120 г. Волгоград, Российская Федерация

\section{Каборе Усман}

Кандидат технических наук, профессор

Политехнического университета Бобо-Дьюласо

atd@vstu.ru

Бобо-Дьюласо, Буркина-Фасо

\section{Зеленский Юрий Олегович}

Соискатель, кафедра автотракторных двигателей

Волгоградского государственного технического университета atd@vstu.ru, vasilyev@vstu.ru

просп. Ленина, 28, 400005 г. Волгоград, Российская Федерация 


\section{ТЕХНИКО-ТЕХНОЛОГИЧЕСКИЕ ИННОВАЦИИ}

Аннотация. В настоящее время является актуальной задача проектирования кулачков, обеспечивающих требуемые характеристики движения звеньев кулачкового механизма в сочетании с его надежностью. В связи с этим в данной работе представлен численный метод профилирования кулачков и примеры его применения для клапанного механизма газораспределения двигателя внутреннего сгорания. Следует отметить, что он также может быть использован при проектировании других кулачковых механизмов различного назначения с целью повышения их надежности.

Существуют два основных подхода к профилированию кулачка. Согласно первому, задается геометрия профиля, а затем определяются функции перемещения скорости и ускорения толкателя по углу поворота кулачка. Во втором случае исходным является закон движения толкателя, на основе которого определяется конфигурация кулачка и данные, необходимые для его изготовления.

Следует отметить, что каждый из традиционных методов профилирования имеет свои области применения. Например, кулачки первой группы, для которых характерна разрывная кривая ускорения толкателя, неприменимы для быстроходных двигателей вследствие неудовлетворительной динамики клапанного привода. Кроме того, как правило, значительную трудность представляет определение оптимальных значений параметров профиля, удовлетворяющего многочисленным требованиям, связанным с газообменом в двигателе, кинематикой, динамикой и надежностью механизма, а также технологическими ограничениями. Задача осложняется еще и тем, что каждому методу соответствует свой набор параметров, определяющих профиль. Наконец, заранее заданные способы описания движения толкателя или конфигурации кулачка даже в случае оптимального выбора параметров профиля не обеспечивают получение кулачков предельной эффективности при выполнении указанных выше условий.

Отмеченные недостатки могут быть устранены при использовании обобщенного численного метода профилирования кулачков механизма газораспределения, который на базе единого подхода позволяет проектировать кулачки, удовлетворяющие различным требованиям.

Ключевые слова: кулачок, профиль, пошаговый метод, числовой метод, профилирование, механизм клапана, толкатель клапана, закон движения. 